\title{
Penerapan Model Cooperative Integrated Reading Composition untuk Meningkatkan Keterampilan Membaca Pemahaman Tema Perkembangan Teknologi
}

\section{Devi Rachmawati}

Universitas Sebelas Maret

desemberakhir31@gmail.com

\section{Article History}

received 30/4/2021

\begin{abstract}
The research was based on the results of students' reading comprehension skills not achieved the minimum completion criteria. The purpose of the research is to improve reading skills in understanding the theme of technological development with the Cooperative Integrated Reading Composition model. This research is a classroom action research with steps of planning, implementing, observing, and reflecting, carried out in two cycles with the subject of class III students at SDN Babalankidul in the academic year 2020/2021. The results showed that students' reading comprehension skills on the theme of technology development increased with the achievement of indicators in the first cycle of $71.4 \%$, and $85.7 \%$ of the second cycle. The increase in reading skills in understanding the theme of technological development is also seen from the learning outcomes of Indonesian language content in the knowledge domain, namely $59.09 \%$ in the first cycle, $86.36 \%$ in the second cycle. The skill domain is $63.63 \%$ in the first cycle, $90.90 \%$ in the second cycle. The conclusion of the study is that the application of the Cooperative Integrated Reading Composition model can improve students' reading comprehension skills.
\end{abstract}

Keywords: Cooperative Integrated Reading Composition, Reading Comprehension Skills, Technology Development Theme.

\begin{abstract}
Abstrak
Penelitian dilatarbelakangi hasil keterampilan membaca pemahaman peserta didik belum mencapai kriteria ketuntasan minimal. Tujuan penelitian yaitu meningkatkan keterampilan membaca pemahaman tema perkembangan teknologi dengan model Cooperative Integrated Reading Composition. Penelitian ini merupakan penelitian tindakan kelas dengan langkah perencanaan, pelaksanaan, pengamatan, dan refleksi, dilaksanakan dalam dua siklus dengan subjek peserta didik kelas III SDN Babalankidul tahun ajaran 2020/2021. Hasil penelitian menunjukkan keterampilan membaca pemahaman peserta didik tema perkembangan teknologi meningkat dengan pencapaian indikator pada siklus I sebesar $71,4 \%$, siklus II sebesar $85,7 \%$. Peningkatan keterampilan membaca pemahaman tema perkembangan teknologi juga terlihat dari hasil belajar muatan Bahasa Indonesia ranah pengetahuan yaitu 59,09\% pada siklus I, $86,36 \%$ pada siklus II. Ranah keterampilan yaitu $63,63 \%$ pada siklus I, 90,90\% pada siklus II. Kesimpulan penelitian adalah penerapan model Cooperative Integrated Reading Composition dapat meningkatkan keterampilan membaca pemahaman peserta didik.
\end{abstract}

Kata kunci: Cooperative Integrated Reading Composition, Keterampilan Membaca

Pemahaman, Tema Perkembangan Teknologi. 


\section{PENDAHULUAN}

Pada masa sekarang perkembangan teknologi semakin pesat, semakin mudah setiap orang untuk mengakses dan mendapatkan informasi. Pada umumnya informasi tersebut dalam bentuk tulisan baik cetak maupun digital. Kebutuhan manusia akan informasi juga semakin meningkat, sehingga setiap orang tentu akan melakukan aktivitas membaca.

Membaca merupakan kegiatan reseptif, yang artinya pembaca menerima pesan atau informasi yang disampaikan oleh penulis dalam sebuah teks bacaan. Pesan yang disampaikan itu merupakan fokus yang dibutuhkan (Dalman, 2017). Sedangkan Abidin (2013) menyatakan bahwa membaca adalah modal awal agar siswa bisa membaca sekaligus tetap menjadi pembaca. Pembelajaran di sekolah rupanya melupakan tujuan ini, sehingga sekolah hanya mampu menghasilkan peserta didik yang dapat membaca tetapi tidak suka membaca. Peserta didik pandai membaca tetapi masih menganggap membaca adalah hal yang membosankan.

Membaca termasuk dalam kegiatan reseptif (menerima) dan memerlukan pemahaman. Membaca tidak hanya sekedar melafalkan huruf, tetapi membutuhkan pemahaman untuk dapat mengerti dan menanggapi informasi yang telah dibaca. Dalman (2017) menyatakan bahwa di sekolah, pembelajaran membaca perlu difokuskan pada aspek kemampuan memahami isi bacaan. Oleh sebab itu, peserta didik perlu dilatih secara intensif untuk memahami sebuah teks bacaan. Hal ini berarti peserta didik bukan menghafal isi bacaan tersebut, melainkan memahami isi bacaan. Dalam hal ini, peran guru sangat besar pengaruhnya terhadap kemampuan peserta didik dalam memahami isi bacaan.

Peserta didik akan cepat dan mudah untuk mengetahui informasi dari bacaan yang telah dibaca dengan memiliki keterampilan membaca pemahaman yang tinggi. Pada sekolah dasar, pembelajaran bahasa memiliki tugas untuk membina peserta didik agar memiliki keterampilan membaca pemahaman. Proses pembelajaran bahasa juga memiliki pengaruh dalam pencapaian tujuan memperoleh keterampilan membaca pemahaman. Proses pembelajaran yang inovatif dan tidak monoton tentunya akan lebih menarik bagi peserta didik, sehingga peserta didik lebih tertarik dan antusias dalam mengikuti proses pembelajaran. Dengan demikian, proses pemerolehan keterampilan membaca pemahaman akan lebih mudah dicapai.

Berdasarkan pengamatan peneliti, kondisi di SDN Babalankidul terdapat masalah dalam keterampilan membaca pemahaman pada peserta didik kelas awal. Berdasarkan observasi yang dilakukan dengan cara mengamati proses pembelajaran, rendahnya keterampilan membaca pemahaman pada peserta didik terjadi ketika peserta didik membaca dan memahami bacaan. Hal ini terlihat ketika peserta didik diminta menemukan informasi dan menceritakan kembali bacaan setelah membaca teks bacaan. Peserta didik mengalami kebingungan ketika harus menemukan isi dan kesimpulan dari bacaan yang telah dibaca. Terkadang peserta didik harus mengulang membaca beberapa kali untuk dapat menemukan isi atau makna dari bacaan yang telah dibaca.

Di SDN Babalankidul, peserta didik tidak serius dalam melakukan kegiatan membaca. Peserta didik bercanda dan mengobrol ketika melaksanakan kegiatan membaca. Selain itu peran peserta didik dalam proses pembelajaran cenderung pasif. Peserta didik malu, tidak berani menyampaikan pendapat di depan kelas. Peserta didik mau menyampaikan pendapat ketika ditunjuk oleh guru. Nilai keterampilan membaca peserta didik kelas III SD Negeri Babalankidul masih dirasa rendah. Dari nilai empat aspek bahasa yang didapat, terlihat nilai rata-rata keterampilan membaca 28 peserta didik kelas III yaitu 59,40.

Berdasarkan permasalahan yang ditemukan, maka diperlukan model pembelajaran untuk mengatasi masalah yang telah diuraikan di atas. Salah satu 
model pembelajaran yang sesuai dalam pembelajaran membaca pemahaman adalah model pembelajaran Cooperative Integrated Reading Composition (CIRC). Muhtadi (2019) menyatakan bahwa pembelajaran CIRC menggabungkan antara pembelajaran membaca pemahaman dengan menulis secara bersamaan, sehingga sesuai dengan keterpaduan prinsip pembelajaran Bahasa Indonesia. Dalam model pembelajaran CIRC peserta didik bekerjasama di dalam kelompok untuk mencari ide pokok, pikiran utama, dan hal-hal yang terkait dengan bacaan. Satu orang peserta didik di dalam kelompok membacakan cerita untuk kelompok, kemudian bersama-sama di dalam kelompok mengerjakan tugas lalu hasil pekerjaan dari kelompok dipresentasikan di depan kelas.

Adapun penelitian yang mendukung untuk memecahkan masalah ini yaitu penelitian yang dilaksanakan Syafitri, Mansurdin (2020) yang berjudul "Model Cooperative Integrated Reading Composition sebagai Upaya Meningkatkan Kemampuan Membaca Pemahaman Siswa di Sekolah Dasar" dengan hasil bahwa Model Cooperative Integrated Reading Composition dapat meningkatkan kemampuan membaca pemahaman siswa SD.

Penelitian yang dilaksanakan Sony Febriawan (2018) yang berjudul "Peningkatan Keterampilan membaca pemahaman dengan model pembelajaran Cooperative Integrated Reading Composition (CIRC) siswa kelas V SD Sekarsuli Bantul". Hasil penelitian tersebut adalah proses pembelajaran membaca pemahaman meningkat. Dibuktikan dengan meningkatnya aktivitas siswa dalam proses pembelajaran pada pratindakan 46,36\% (kategori rendah), siklus 1 59,09\% (kategori tinggi), siklus II 72,27\% (kategori tinggi). Selain itu nilai rata-rata keterampilan membaca pemahaman meningkat dari pratindakan sebesar 56,73\% (kategori cukup), siklus I sebesar 77,27\% (kategori baik), siklus II 79,36\% (kategori baik).

Berdasarkan uraian permasalahan maka terbentuk suatu rumusan apakah penerapan model Cooperative Integrated Reading Composition dapat meningkatkan keterampilan membaca pemahaman tema perkembangan teknologi pada peserta didik kelas III SDN Babalankidul. Rumusan ini mendasari tujuan dilakukannya penelitian yaitu untuk meningkatkan keterampilan membaca pemahaman tema perkembangan teknologi pada peserta didik kelas III SDN Babalankidul.

\section{METODE}

Jenis penelitian dalam penelitian ini adalah penelitian tindakan kelas yang dilaksanakan dalam dua siklus secara daring (dalam jaringan) dan luring (luar jaringan). Masing-masing siklus terdiri dari empat tahap yaitu (1) perencanaan, (2) pelaksanaan, (3) pengamatan, dan (4) refleksi. Pelaksanaan penelitian di SDN Babalankidul dengan subjek peserta didik kelas III tahun ajaran 2020/2021 yang berjumlah 22 peserta. Teknik dan alat pengumpulan data yang digunakan adalah menggunakan teknik observasi, tes, dan dokumentasi. Analisis data kuantitatif digunakan untuk menentukan peningkatan keterampilan membaca pemahaman peserta didik sebagai pengaruh dari setiap tindakan yang dilakukan oleh peneliti. Indikator keberhasilan penelitian yaitu ketuntasan minimal peserta didik pada keterampilan membaca pemahaman menggunakan model cooperative integrated reading composition mencapai lebih dari atau sama dengan $75 \%$ dengan nilai KKM 75 .

\section{HASIL DAN PEMBAHASAN}

Penerapan model Cooperative Integrated Reading Composition untuk meningkatkan keterampilan membaca pemahaman peserta didik dilaksanakan dalam 2 siklus. Setiap siklus terdiri dari 2 pertemuan. Pembelajaran dilaksanakan dengan menerapkan langkah-langkah pembelajaran model Cooperative Integrated Reading Composition yaitu (1) orientasi, (2) organisasi, (3) pengenalan konsep, (4) publikasi, 
dan (5) penguatan refleksi. Pada langkah orientasi dan organisasi dilaksanakan secara daring asinkronus melalui whatsapp groub. Langkah pengenalan konsep dilaksanakan secara luring dengan berkelompok di rumah salah satu anggota kelompok. Langkah publikasi, penguatan, dan refleksi dilaksanakan secara daring sinkronus melalui zoom meeting.

Hasil rekapitulasi data penelitian tindakan kelas ini menunjukkan adanya peningkatan keterampilan membaca pemahaman tema perkembangan teknologi peserta didik kelas III SDN Babalankidul pada siklus I dan siklus II dilihat dari indikator ketercapaian keterampilan membaca pemahaman dan ketuntasan hasil belajar peserta didik. Peningkatan tersebut dapat dilihat pada tabel dan diagram berikut.

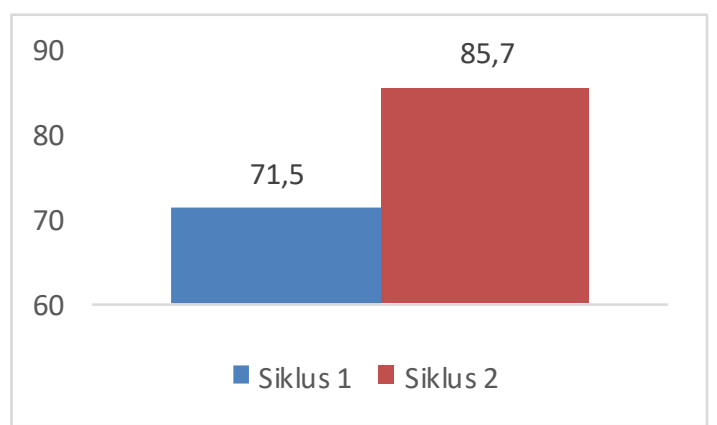

Gambar 1. Ketercapaian Indikator Kinerja Keterampilan Membaca Pemahaman

Tabel 1. Rekapitulasi Hasil Belajar Peserta didik Kelas III

\begin{tabular}{lccccc}
\hline \multicolumn{1}{c}{ Keterangan } & \multicolumn{2}{c}{ Pengetahuan } & \multicolumn{2}{c}{ Keterampilan } \\
\multicolumn{1}{c}{ Siklus } & $\mathbf{I}$ & II & I & II \\
\hline Nilai Tertinggi & 96 & 96 & 90 & 89 \\
Nilai Terendah & 70 & 74 & 68 & 73 \\
Tuntas & $13(59,09 \%)$ & $19(86,36 \%)$ & $14(63,63 \%)$ & $20(90,90 \%)$ \\
Tidak Tuntas & $9(40,90 \%)$ & $3(13,63 \%)$ & $8(36,36 \%)$ & $2(9,09 \%)$ \\
Rata-rata klasikal & 79,72 & 83,27 & 79,00 & 81,54 \\
\hline
\end{tabular}

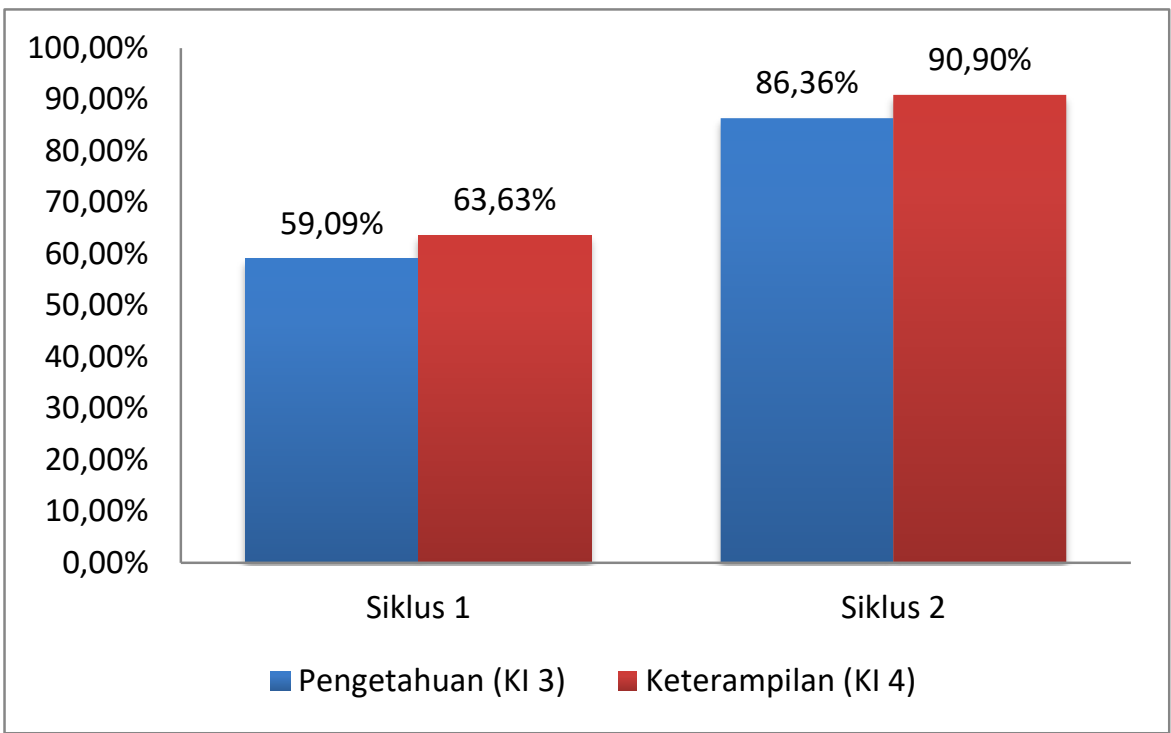

Gambar 2. Hasil Belajar Peserta Didik Kelas III 
Berdasarkan gambar 1 dapat dijabarkan bahwa terjadi peningkatan ketercapaian indikator keterampilan membaca pemahaman sebanyak $14,2 \%$ dari siklus I ke siklus II. Pada siklus I ketercapaian sebesar 71,5\% (5 dari 7 indikator tercapai) dan pada siklus II menunjukkan ketercapaian sebesar $85,7 \%$ (6 dari 7 indikator tercapai). Keterampilan membaca pemahaman diamati melalui observasi pada saat pembelajaran asinkronus dan sinkronus menggunakan indikator keterampilan membaca pemahaman yang disampaikan oleh Widasari (2017) melaui observasi langsung yang dilakukan oleh peneliti dibantu dengan teman sejawat sebagai observer dengan tujuh indikator yang diharapkan ada, yaitu: dapat membaca teks bacaan dengan benar dan jelas, dapat menjawab pertanyaan yang berhubungan dengan teks, dapat menemukan kalimat utama pada setiap paragraf dalam bacaan, dapat meringkas isi bacaan, dapat mengartikan kata-kata sukar dalam teks bacaan, dapat menuliskan informasi dalam bacaan, serta dapat menjelaskan makna yang terdapat dalam bacaan.

Kemudian dari tabel 1 dan gambar 2 di atas dapat diketahui bahwa terjadi peningkatan hasil belajar dalam ranah keterampilan dan ranah pengetahuan pada tema Perkembangan Teknologi khususnya muatan Bahasa Indonesia. Terlihat bahwa ketuntasan hasil belajar ranah keterampilan meningkat $27 \%$ dari siklus I $63,63 \%$ (kategori cukup) ke siklus II 90,90\% (kategori baik sekali). Hal ini menunjukkan 20 peserta didik tuntas untuk ranah keterampilan. Begitu juga dengan ketuntasan hasil belajar pada ranah pengetahuan yang diambil dari nilai evaluasi muatan Bahasa Indonesia yang mengalami peningkatan sebesar 27,27\% dari siklus I 59,09\% (kategori cukup) dan siklus II 86,36\% (kategori sangat baik). Hal ini menunjukkan bahwa sebanyak 19 peserta didik dinyatakan tuntas untuk ranah pengetahuan.

Data yang terdapat pada tabel dan gambar sesuai dengan pendapat Zulkifli (2015) bahwa peserta didik sekolah dasar diharapkan dapat menguasai tiga kemampuan supaya pembelajaran dapat berlangsung dengan baik yaitu matang menulis, membaca, dan berhitung. Berdasarkan pendapat tersebut, membaca merupakan salah satu kemampuan yang harus dikuasai oleh peserta didik dalam proses pembelajaran. Membaca perlu dipelajari secara mendalam, khususnya membaca pemahaman dengan menggunakan Cooperative Integrated Reading Composition.

\section{SIMPULAN}

Simpulan dari penelitian ini adalah penerapan model Cooperative Integrated Reading Composition dapat meningkatkan keterampilan membaca pemahaman tema perkembangan teknologi pada peserta didik kelas III SDN Babalankidul tahun ajaran 2020/2021. Hal tersebut terlihat dari ketercapaian indikator yang merujuk pada indikator keterampilan membaca pemahaman menurut Widasari (2017) dengan rincian pencapaian indikator pada siklus I sebanyak 71,5\%, siklus II sebanyak $85,7 \%$. Ketuntasan hasil belajar ranah keterampilan meningkat $27 \%$ dari siklus I sebesar 63,63\% (kategori cukup) ke siklus II sebesar 90,90\% (kategori baik sekali). Begitu juga dengan ketuntasan hasil belajar ranah pengetahuan yang diambil dari nilai evaluasi muatan Bahasa Indonesia mengalami peningkatan sebesar $27,27 \%$ dari siklus I sebesar 59,09\% (kategori cukup) dan siklus II sebesar 86,36\% (kategori sangat baik). Melalui penelitian ini, guru sebaiknya dapat menerapkan model pembelajaran Cooperative Integrated Reading Composition secara konsisten dalam pembelajaran keterampilan membaca pemahaman. Selain itu, guru hendaknya dapat membiasakan peserta didik untuk terbiasa dalam kegiatan membaca.

\section{DAFTAR PUSTAKA}

Abbas, S. (2015). Pembelajaran Bahasa Indonesia yang Efektif di Sekolah Dasar. Jakarta: Departemen Pendidikan Nasional Direktorat Jenderal Pendidikan Tinggi Direktorat Ketenagaan. 
Abidin, Y. (2013). Pembelajaran Membaca Berbasis Pendidikan Karakter. Bandung: Refika Aditama.

Arikunto. (2015). Penelitian Tindakan Kelas. Jakarta: Bumi Aksara.

Aunurrahman. (2012). Belajar dan Pembelajaran. Bandung: Alfabeta.

Dalman. (2017). Keterampilan Membaca. Jakarta: Rajawali Pers.

Muhtadi, A. (2019). Modul 3 Pembelajaran Inovatif. Jakarta: Tim Direktorat Pembinaan GTK PAUD dan Dikmas.

Nurgiyanto, B. (2015). Penilaian Pembelajaran Bahasa Indonesia Berbasis Kompetensi. Jakarta: PT. Bumi Aksara.

Santosa, P. (2008). Materi dan Pembelajaran Bahasa Indonesia SD. Jakarta: Universitas Terbuka.

Syafitri, C.R. (2020). Model Cooperative Integrated Reading and Composition sebagai Upaya Meningkatkan Kemampuan Membaca Pemahaman Siswa di Sekolah Dasar. Jurnal Pendidikan Tambusai. Halaman 1335-1346. Volume 4 Nomor 2 Tahun 2020. SSN: 2614-6754 (print) ISSN: 2614-3097 (online)

Yamin, F. (2018). Penerapan Model Pembelajaran Cooperative Integrated Reading and Composition (CIRC) dalam Meningkatkan Hasil Belajar Membaca Pemahaman Siswa. Cokroaminoto Journal of Primary Education 2018. 1(1), 5257. 